\title{
Support of Self-Criticism and Creative Thinking Based on the Use of ICT as an Alternative to Classical Education
}

\author{
Gabriela Sláviková - Juraj Tej ${ }^{*}$
}

\begin{abstract}
The present period is characterized by a rapid development of ICT. The possibilities of using internet represent newer ways of communicating with many people, regardless of the distance. The development and the use of new technologies open up many possibilities for communication and education. The capability of using ICT, to teach pre-recorded principles, and to develop key competences of students has become one of the very important tasks of contemporary schools, both on the teachers' and student's side. One alternative is online courses.
\end{abstract}

Key words: ICT, managerial simulation, education, eLearning.

\section{Introduction}

The integration of information and communication technologies (ICT) into education in all schools and in lifelong education systems, with an emphasis on key competencies, information education, innovative educational strategies, eLearning, virtual educational methods, virtual universities, on-line learning, multimodality, etc., are considered a key educational priority within the framework of strategies and the framework of multinational documents, declared by the European Union.

The experience of teachers as well as scientists show a preference for activity based on learning - learning by problem solving, as a better and more effective way for the acquisition and knowledge employment. This context highlights the necessity of educational dialogue and the extensive use of methods based on creativity, activity and cooperation. Many of these approaches are supported by ICT, which simultaneously already markedly affect behaviour as well as educational content.

The authors - based on their own experience with learning through ICT have investigated how managerial participants in simulation courses respond to creative, supported learning. Part of the research was a comparison of research samples of university students from Slovakia.

\footnotetext{
* Gabriela Sláviková, Dubnica Institute of Technology in Dubnica nad Váhom, Dubnica nad Váhom, Slovakia; slavikova@dupres.sk

Juraj Tej, Prešov University of Prešov, Prešov, Slovakia; juraj.tej@unipo.sk
} 


\section{From the boredom zone to the comfort zone}

\subsection{Modern forms of education and positioning into comfort zone}

The capability to use ICT, to implement learning on reassigned principals and key competencies of students' development are becoming one of the very important tasks of contemporary schools on the part of teachers as well as on the part of students.

It is important to integrate ICT into university preparation as well as into whole academic environment. There is no doubt that introducing ICT into the educational process is a necessity today; all the advantages of PC supported education, with its connected problems of nowadays, are:

- assurance of ICT functionality in school for a longer period of time, i.e. even after contract expiration, or expiration of the operational life of the ICT equipment. This task often requires a great (even superhuman) effort of school management;

- finding an effective proportionality between traditional education and education supported by ICT, so as to meet students' requirement and also teachers' psycho hygienic criteria;

- positive combination of results achieved by classic and by computer supported training;

according to Burgerová (2001) also:

- use of Internet,

- effective individualization in computer support of education,

- use of multimedia in the educational process.

Whether today or in recent decades, at home as well as abroad, renowned, famous but also obscure educational institutions increasingly offer different study types with influence of new forms, the realization of these is seriously affected by development in ICT area (Straková et al.).

For several years the Internet course "eEkonomia" has been used, authorized by the institution of Junior Achievement Slovakia (www.jasr.sk) which - similarly to different managerial simulation trainings offered by various grades of schools - has brought concrete results. Both products meet the highly demanding contemporary requirement - to make the education process more attractive (also through the use of ICT equipment since students can be overloaded by using ICT, both at home and at school). Similarly, it is important to consider the possibility of offering a high-standard business, economic and financial education based on "learning by experience" principles. Its implementation in the classroom as well as in distance education provides participants with an adequate comfort level and into a position that does not bore or stress them. 


\subsection{The relation of the comfort zone and state of flux of modern educational forms}

Distance learning represents a challenge for students who decide to participate in it. Brundage, Keane, and Mackneson on the webpage of Idaho University have identified the basic assumptions of success in distance learning. They consider the most important that students feel a high responsibility for controlling the throttle of their educational process and for a successful participation in it which means:

- students must be aware of what they want to achieve - what are their goals as well as possibilities and the means available for their achievement;

- students must know their strengths and weaknesses in order to effectively utilize them in achieving success;

- also important is a sufficient level of self-confidence in order not to give up after the first failures;

- also critical is the role of the instructor/teacher and other members of the educational group who reflect problems and successes and thus help to identify areas in which it is necessary to improve their current performance;

- since the educational process is not run in a traditional way in a traditional space where trainees are in every day contact, it is necessary to provide an effective method of mutual communication within virtual classes;

- an indispensable part is self-reflection on the educational process - thus, we want to support a responsible attitude by trainees to the progression of their process (Brundage et al., 1993).

Education by means of ICT in simulation training enables students:

- to work with information in real time;

- to see the result of their creative work immediately;

- to try to work in area which is, in real business, very responsible and in case of failure is associated with high financial losses;

- to obtain experience with work in which a high competence is required;

- the re-enactment makes it possible to avoid mistakes and make the best of alternative solutions;

- the creation of alternative solutions supports their creativity and the perception of the need for erudite managerial decision.

The model of "comfort" and "stress" zones implies that during personal development everyone acquires skills, experiences (positive but also negative), maintains own behaviour and communication models and builds his own value chain. He also discovers his own goals and sense of life and thus creates a comfort zone (experience and safety zone) all around themselves. Everything included in this zone, is "absorbed and interiorized" by the participant (student) (Tej and Krasnodębski, 2009). When the student steps out from this zone into an unknown area, he actually steps into the area of growth/development. The 
transition from one zone to another zone is for the student simultaneously "stimulating - troublesome - proactive". A zone acts like a dynamic system.

When exposing the student to the risk of an uncertain outcome/result, the zone expands - in those areas which are under the teacher's influence and develop student's creative approach to the addressed issues. On the contrary, long-term non-use of any of the developed abilities or skills reduces the acquired level to the original value, even to the "boredom" area. The transition associated with the challenge of subjective "risk" (social, psychological or physical) which induces a positively motivating stress, is partially overlapped with the state of optimum survival "flow" (flux, stream, passage). "Flow" is a stage in which emotions are completely concentrated on the services of a particular activity connected with learning. At this stage, emotions are not only incorporated and expressed, but also constructive, full of energy and closely interconnected with activity.

The internet course author as well as the simulation facilitator must necessarily prepare them (the courses) so that: (Fig. 1):

- draw students out of "boredom" state caused by passive inert of ICT;

- positively exploit the student's embarkation into the zone of (positive) "stress" which has an optimal stimulating effect;

- keep the student as long as possible in the flow state which enables him to be at the same time creatively active and to study;

- repeated experiences with the course or during the simulation enable the students to use their own creative solutions.

Figure 1 The state of flow

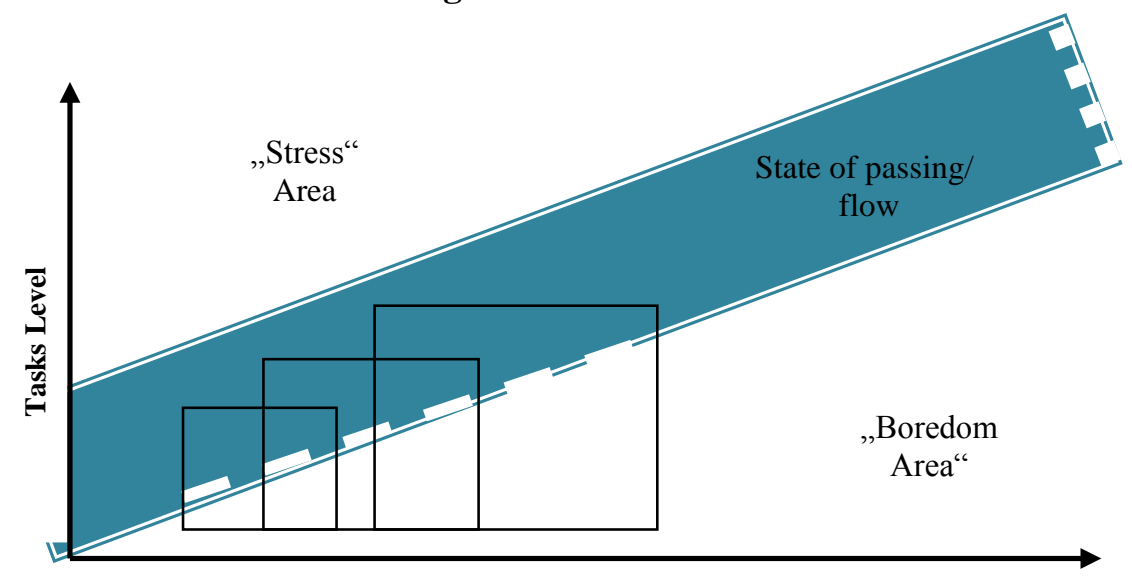

Level of knowledge, skills and abilities

Source: Másilka (2003)

State of flow occurs only when the specific activity fully employs all the participants' abilities. If the activity is too easy, people are bored. However, 
demanding/difficult activity arouses anxiety. The state of flow arises somewhere in the area between "boredom" and "stress and mostly depends on facilitator's (teacher's) work. Facilitators try to keep students in this state for as long as possible. Repeatedly increasing simulated task difficulty increases the level of the participant's (student's) knowledge, skills, abilities and creativity - this induces a shift in his expertise and competence acquired during the course or simulation to a higher qualitative level (not only in professional activities which is desirable in the contemporary process of education), but experiential pedagogic projects are also characterized by their impact on personality (Birknerová, 2010; Jurková and Ferencová, 2011; Ali Taha and Tej, 2012). The objectives of particular projects vary, they are as follows:

- $\quad$ development - acquisition of new knowledge, skills and development of abilities;

- $\quad$ reformation - acquisition of new knowledge, skills and development of abilities which students use to correct and improve the existing personal status (or the status of the group);

- $\quad$ recreation - entertainment, rest;

- creation of good informal relationships in a group - atmosphere, teambuilding;

- $\quad$ diagnostics - evaluation, recommendations, solution proposals;

- treatment - improvement/correction which runs on the basis of feedback alongside the empowerment by the facilitator - educationalist.

Educational internet courses most frequently "work" with the first two target levels, although it remains possible to reach also the next categories with rising ability development and problem solving. Courses and simulations should be built on the principles of success and on motivation cumulating in the next activity (whether during the course or later, in professional life). If for any reason a failure occurs or if too high expectations induce frustration, stress or blockage in an on/line course participant - (student's side), it means that the educationalist must have properly selected feedback. The student together with the educationalist strive to find a positive response to the problem and in successive steps look for an improvement. This approach is called "positive orientation to the mistake" (Brundage et al., 1993). Programs without any feedback element are not appropriate in the educational process.

Within the issue discussed in this paper it is possible to apply Tuson's model (Fig. 2) which consists of three zones:

- the comfort zone - a zone in which students feel safe; they know the environment, the people, as well as the operating principles. However, they learn nothing new; they work only on the basis of previous experience and knowledge; they have no need and motivation to change anything;

- the learning zone - a space, where humans encounter actual boundaries of their abilities and skills while finding out that it is possible to develop them. Generally, it is about generating incentives from the internal or external 
environment behavioural change or for working according to the established rules. This segment corresponds with the flow zone in Fig. 1;

- the panic zone - crosses the threshold of the current possibilities of the person. In terms of learning it is not possible to "move" (advance) them anywhere because there is a risk of regression (recourse) which occurs due to negative experience and fear. This zone corresponds with the area of "stress" on Figure 1 (Balogová, 2009).

\section{Figure 2 Tuson's model}

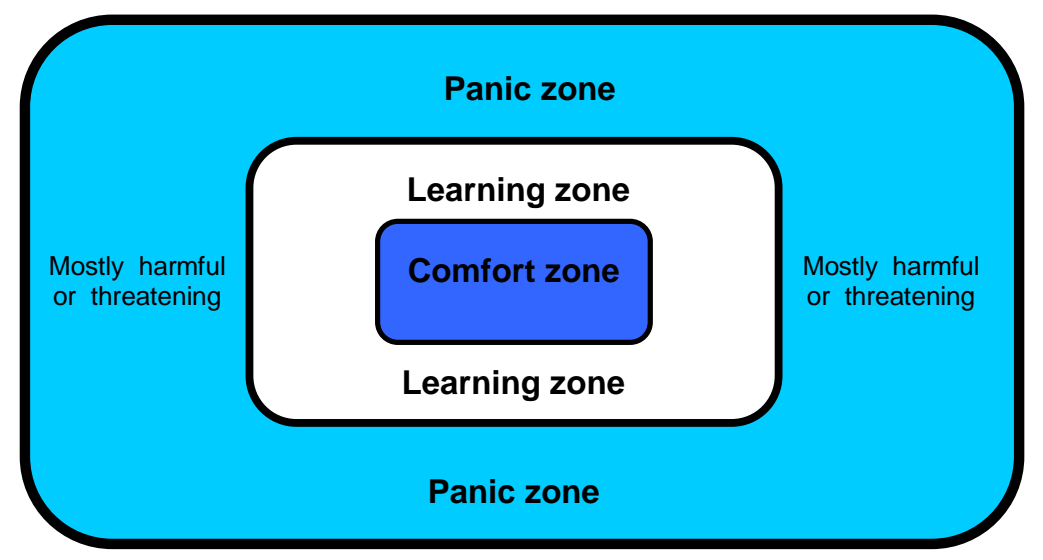

Source: Balogová (2009); Tej and Krasnodębski (2009)

The space, which each of us has - including participants of distance learning courses or managerial simulation - is mapped in detail. To stimuli that affect us, we respond through memorized and proven procedures. We feel comfortable and safe in the comfort zone, nothing threatens us. In this comfort zone, we can theoretically all our lives and its limits are not even realized. Theoretically, it is possible to remain in the comfort zone all life and even not to be aware of its boundaries. In this zone a person resists news and avoids crises situations. Course participants, students, and simulation participants go outside of the comfort zone. They get beyond the borders of the known and unknown, "learned" and "brand-new", "safe' and "risky", i.e. go beyond their own comfort zone boundaries and temporarily leave this zone.

Stepping outside the learning zone is connected with new stimuli which participants are not accustomed to, and on which they may not have patterned behaviour. This situation could motivate participants to extraordinary performances, but it could also be uncomfortable and stressful. The method of coping with the novel situation to some extent determines the behaviour of participants in the future. If a participant steps out appropriately far, overcomes fears and stress and copes with the situation, they will usually feel very 
comfortable. Thus the participant learns something new and widens their comfort zone. This may not always be about new knowledge and new terms; it could also be about obtaining an awareness of being able to do more, i.e. an ability to take risk, to be creative in an area which is unfamiliar.

Sometimes the abandonment of the comfort zone goes badly wrong and participants are not able to manage the situation - they are lost in the panic zone. Their zone of comfort has not expanded, but has even decreased.

It happens exceptionally that participant can handle the situation caused by stepping out from their comfort zone, but the experience is accompanied by such uncomfortable feelings that the participant does not want to experience it again. They usually realize and are reconciled with a fact that this direction is not suitable for them and the next time they avoid such activity.

Managerial simulations programmatically force participants to step outside their comfort zone. They uncover new possibilities in themselves which encourage them to step into the learning zone. Their goal is particularly an aspiration to self-development. The basis of work is positive feedback and the principle of transferred experience. If simulation or course participants are able to handle tasks better than they expected, it strengthens their decision-making in real situations, too.

This is, in essence, the alternative educational method, which through ICT equipment leads to new perspectives and creative thinking improvements, i.e. to the transfer of experience from the educational process to work as well as to practical life.

\section{Methodology}

Modern technologies create an open global information and communication space and set the teacher as well as the school into a new position (sometimes in a positive and sometimes in a negative meaning). Data, which are collated with opinions of graduates, were obtained in 2012 at the Faculty of Management of Prešov University in Prešov (the Slovak Republic) by a research questionnaire. The dependence between individual classification symbols was evaluated by means of quantitative statistics (e.g. contingency coefficients); consistency was verified by a Chi-square test.

\section{Results}

\subsection{The experience of a real internet course and managerial simulation taught through the medium of ICT}

Today, most educationalists look for opportunities to make the teaching process at school more attractive and try to offer their students a high-standard (business, economic or financial) education based on experiential learning methodology, offering the possibility of the maximum exploitation of students' hidden 
creativity (which is often inhibited, underestimated or unexploited by traditional educational processes).

Junior Achievement Slovakia, NPO (JASR) is a not-profit-making educational organization. From its creation it has undergone several important changes. As an institution it was established (at his own request) by the Ministry of the Interior (No. 203/2-93/030004) as an international non-governmental organization. From $26^{\text {th }}$ July 2008 it has operated as a non-profit organization: Junior Achievement Slovakia, NPO. It is a member of the world-wide network "Junior Achievement Worldwide" and European network "Junior AchievementYoung Enterprise Europe".

The Economic educational programmes of Junior Achievement have a long-term world-wide history which dates back to 1919 when a non-profit educational organization "Junior" was founded in the USA. In 1989, the programmes of Junior Achievement were offered in 15 countries around the world. Junior Achievement in Slovakia has been creating programmes (software) since the spring of 1992. Junior Achievement offers students and teachers programmes, textbooks and methodical materials as well as training courses for educationalists and volunteers, supplementary services and activities based especially on experience for free.

Several years experiences demonstrate that knowledge, skills and abilities which students obtain on the programmes of JASR properly fill the gap in students' practical school preparation at different school levels (elementary, secondary and higher education). The programmes provide educationalists practical and didactic tools for another type of students' preparation - helping them to decide on their future professional orientation using ICT

The organization decided to create an online course after several years of experience in teaching from textbooks and based on this experience and the use of simulation programs. The first textbook was a transcription of an original American textbook that had been properly prepared and offered the students sufficient study comfort. Although it was not a simple school subject (course) it did not force students into the panic zone - just because it exploited newly discovered creative teaching methods.

In 2001, authors Tej and Luticova were given the opportunity and were content to create - based on another original textbook - a new textbook with Slovak content and innovative materials. Textbooks entitled "Applied economy I. and II." are still in use and serve as an appropriate demonstration of alternative textbooks, in terms of methods of teaching (not content). The trinity of authors (Tej, Luticova and Skladanova) using the above mentioned textbooks, prepared an internet course with the official name of e-Economy - a virtual course in economic theory (Tej et al., 2001) which has been used from 2003 and has gained great popularity.

Managerial simulation training is a one-semester programme based on computer simulation in which students acquaint themselves with a simulated market 
environment in a business area on a national and international level or with banking. The goals of programmes are simple, linked to the above mentioned internet course "e-Economy". They are:

- to obtain experience from team work and team decision processes,

- to develop the students' ability to anticipate the consequences of their own decisions,

- to practice basic economic theory through the medium of economic experiment,

- to better follow economic principles and the regulations of market economy,

- to understand the connections between individual economic processes on a micro- and macro level and their mutual influence up to level of their consequent direct impact on the economic decision-making of a firm,

- to develop a creative approach in participants in economy and management,

- to improve the equality of higher education by using economic simulation programmes in the interactive creative educational process.

Titan is the name of an assessed managerial economic simulation exercise. It is a computer simulation in which $2-8$ teams compete in the market in the production and sale of the same product. The programme enables you to add to the games another player generated by the computer (for students, it is a great pleasure and good feeling to beat such a player by their decisions). It is possible to change the simulation by setting various parameters, for example: simulation of expansion, recession, change of tax tariffs and interest rates. The responsibility of the students is to outperform competitors in profits, incomes and share of market. Managerial simulation exercises in a competitive struggle, give students the opportunity to become familiar with financial and accounting reports in a firms and branches and their interpretation. Competition encourages students to think about basic factors of production, marketing and financing and relate them to economic principles which they have learnt while studying economics at school. During the simulation they set prices for their products, determine the volume of production, plan a budget for marketing, research and development, and invest in buildings, machines and equipment. They also decide about investments in the local community, within their socially responsible entrepreneurship.

The ability to think and plan analytically is necessary for these decisions. Thus the simulation is not only a source of an emotional and exciting competition, but also a very effective pedagogic tool. If the participants are managers, the simulation becomes knowing/understanding the personal characteristics of oneself and of the team - especially increasingly difficulty simulated parameters. Education based on the projects of NPOs (non-profit organizations) is elicited from team co-operation in the classroom during the learning unit. It is possible to describe it following the British expert on management J. Adair, who emphasizes the need for balanced orientation of a group and facilitator on goals, processes and the personal needs of team members (Fig. 4). He draws attention 
to the real negative implications of a standing long-time preference for one of the listed factors. Using of Adair's (1993) modified scheme, it is possible for the group to judge their behaviour not only during partial tasks, but on the basis of immediate experience it is possible to think also about the prevailing orientation in the educational process. Team members obtain their membership following their own choosing or following the teacher's/facilitator's decision. The basic need which they confront as a team in education IS the need for education. During simulations they can discover other needs, too, e.g. the need for success, the need for appreciation from the team, the need to demonstrate creativity, etc. These factors, together with other processes, create the very necessary balance in education using ICT methods, which have to fill a supporting role (and not to be a primary means of education, the basic educational element).

Figure 3 Dynamic team equilibrium

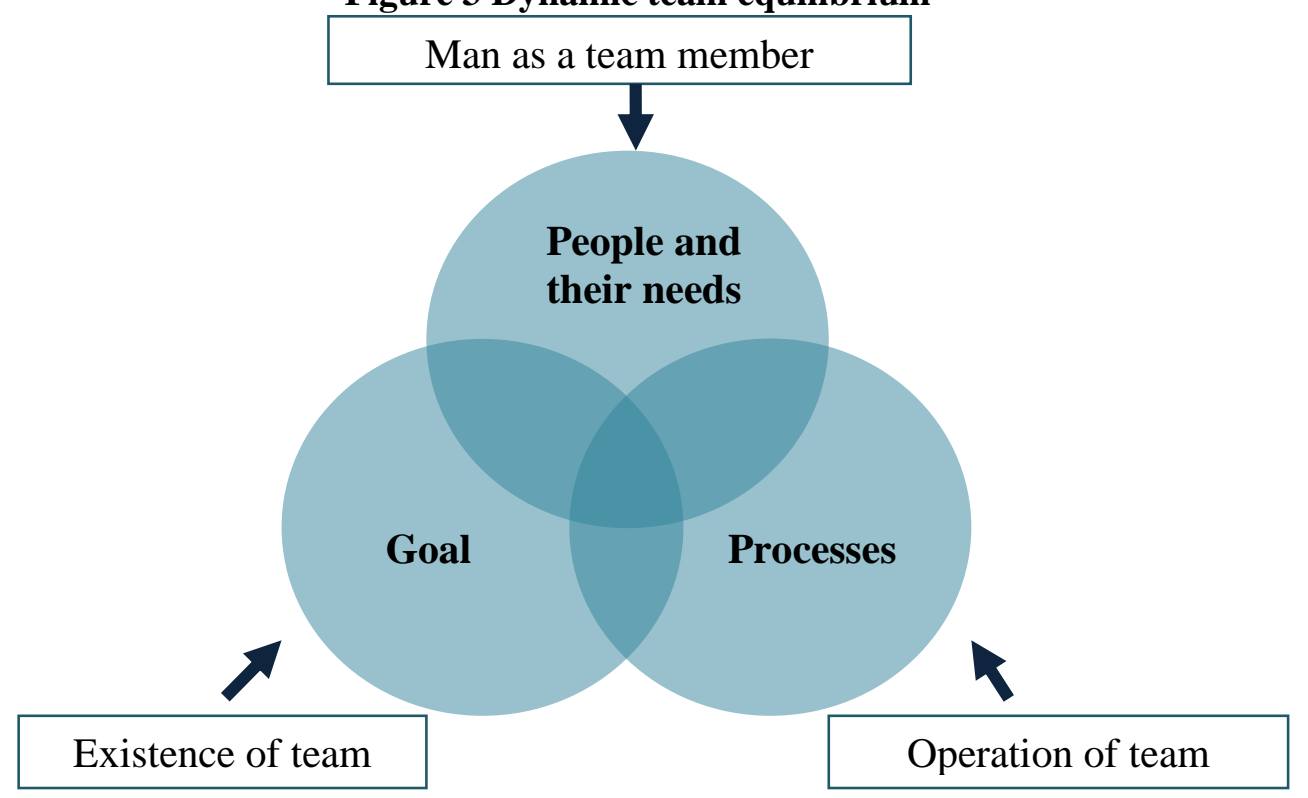

Source: processed and modified by authors according Adair (1993, in Atkinson and Flint, 2001)

If people in the working process correctly dovetail into certain predetermined formal structures, they play roles equivalent to their positions, work with various amounts of information and exercise various authority. In internet courses and in managerial simulations, the situation is absolutely different. The formal structure is not valid; an informal structure only starts to be created. Tasks are usually submitted to the group as a whole; information is identical for all; nobody has predetermined mandate to decide in the group's name. When modelling a 
situation, it is possible to create a hierarchical structure in the group and to assign tasks to the leader. Then the teacher/facilitator can monitor how the leader aligns with their position and provide them with feedback regarding leadership style. In a specifically defined simulation, it is the best to solve problems in a natural group.

Specialists on the particular problems appear very rarely because unusual tasks are created and thus unprecedented for each participant (Svatoš and Lebeda 2005). In this situation, nobody is favoured (all course or simulation participants are on the same "starting line"). All have identical initial conditions and manifest themselves according to their natural dispositions. After a time, the uncertainty, chaos and tension within the group an informal structure start to form initiated by the new situation, and this informed structure does not necessarily correspond with the normal working hierarchy. For the facilitator as well as the teacher it is very useful to see them in such a situation - it is interesting to note and observe who the author of original ideas is, who the leader in creativity is, who the main "driver" is, who is able to analyse the situation, who can offer a proper frame for the group work and who is able to co-ordinate the activity of the team. After this observation it is clear who primarily is willing to present their own ideas even at the risk of possible failure; who is afraid of self-exposure, and who buck stands aside from action and only formally demonstrates their participation (which is very difficult to find on an internet course).

The way in which individual group members cope with an altered situation indicates markedly the state of the internal situation and the group culture in a company.

In an environment where there is trust, people easily release, are spontaneous, are creative and are not afraid to take risks, in general they support each other and achieve good results. Typically, there is immediate openness in evaluating their own work. They feel free to reveal and admit partial failures that serve as a useful source of guidance. Very rarely do we encounter a group where people humiliate each other. Such participants typically prefer apologetics, shallow expressions, a hostility to self-reflection - these people very often act as if they were the most perfect of people, who have nothing to improve. Even evident failures at solving task, they strive to present like a success, and possibly trivialize and ridicule the simulation. Through a variety of ways they try to escape from confrontation with their own mistakes which they cannot admit in front of other team members. If in simulations, they are looking for something, in most cases it is the maximum exhibition in front of others, not an opportunity for self-development. It is not necessary to speak about the atmosphere in the group. Fortunately, such groups are really seldom. 


\subsection{Research of creative methods perception among course and simulation participants}

The disinterested reader might laically assume that the essence of the creative approach in managerial games is the activation of creativity and original thinking in solving problems. Their goal is mastering creative and innovative thinking or to teach creatively to learn how to apply it in practice, in analysing and solving problems, which requires a heuristic approach because they are always to a certain extent new (claiming a creative approach and intuition). The importance of creativity, strategic thinking, the issue of the formation and management of the team and ultimately the impact of ICT allows the development and application of different entrepreneurial simulations, which are today also called management games, which offer a complex and detailed insight into the management of institutions (Kršáková, 2005). Management games are perceived as simulation games, supporting creative thinking and approaches which are one method of education based on quasi-realistic experiences (Hanuš and Chytilová, 2009). They are games that simulate hypothetical (but not unreal) business, economic or other environments and thus allow for active social communication between living participants on the principle "non-real - realistic". Currently they are used not only as a tool for managerial knowledge, skills and competence development, but also as tool for education in scholastic environments. Creative games can be addressed to various groups of participants and can be used in their teaching practice as a means of practicing on concentration and creativity. Their content and timing are very diverse (Beermann and Schubach, 2009).

The importance of creativity was recently demonstrated by a meeting of the Council and the representatives of the Member States of the European Union on 22nd May 2008 on the promotion of creativity and innovation through education and training (Council conclusions, 2008). In its conclusions, the Council stated that creativity is the prime source of innovation, which is considered to be the main driving force of growth and wealth creation, and is the key to improving social policy and an important tool in addressing global challenges such as climate change, health care and sustainable development. Education systems at school level combine the development of specific knowledge and skills along with general skills related to creativity, such as curiosity, intuition, critical thinking, problem solving, experimentation, risk taking and the ability to learn from mistakes (Gorej, 2010). The Council emphasized the importance of collaborative approaches and a focus on the student in innovative learning environments. To put these ideas into life, it is necessary to have a positive attitude to the long-term orientation of the school policy and educational practice to creativity. The lack of creative approaches in vocational education in Slovakia has also been highlighted by other authors (Tej and Ali Taha, 2011; Ali Taha and Tej, 2012). 
In connection with these identified problems, we decided to verify our claims through a survey among university students studying management and preparing for a managerial career (at the University of Prešov in Prešov). A questionnaire was used in the survey and snowball sampling as a way of infiltration - which is used when it is necessary to get as many respondents from a specific group as possible (Atkinson and Flint, 2001). Addressing and questioning respondents is carried out in such a way that after finding a satisfactory respondent, they are asked to recommended other suitable respondents until a satisfactory number of completed questionnaires is received. Infiltration by means described enabled the implementation of the survey among a specific group of respondents, which brought adequate results.

The survey was conducted in March 2012. Overall, 280 respondents were addressed while the respondents were participants of an internet course (at least one) and were familiar with managerial computer simulations (at least one). It was possible to use 271 filled questionnaires (97\% of all questionnaires) for processing results. The composition of the sample according to gender is shown in Tab. 1.

\begin{tabular}{|c|c|c|c|c|c|}
\hline \multicolumn{2}{|c|}{ Male } & \multicolumn{2}{c|}{ Female } & \multicolumn{2}{c|}{ Sum } \\
\hline Abs. & Rel. & Abs. & Rel. & Abs. & Rel. \\
\hline 105 & 38,75 & 166 & 61,25 & 271 & 100,00 \\
\hline
\end{tabular}

Table 1 Structure of respondents according gender

The structure of respondents corresponds to the current ratio of students studying management programmes. At present time women predominate in management faculties in Slovakia.

The following text shows some of the results of the survey. It was evaluated using seven questions which confirm the thesis and the conclusions that have been presented above.

\section{The contribution of online courses (Fig. 5)}

Students could express their opinions at 3 qualitative levels. The lowest level of evaluation (low contribution of online courses) was selected by only $3 \%$ of respondents. The largest group, specifically $57 \%$ of respondents evaluated the benefits of online course as average. $40 \%$ of respondents perceived the contribution of online course as being high. Contingency dependence in the answers of respondents by gender dependence is high - 0.828 (Chi-squared 0.053 points shows no significance of differences by gender). The overall positive result $(97 \%)$ is a sufficient reason for the teacher to use this option in the educational process. 
Figure 4 The contribution of online courses

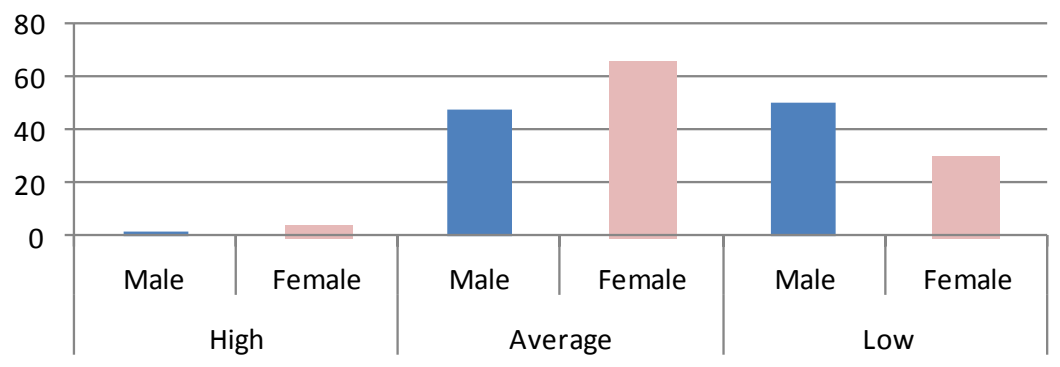

Source: Authors

Preferences for an online course with the participation of a tutor (Fig. 5)

We obtained similar results in the next opinion survey conducted on the internet course by a tutor.

Figure 5 Preferences for online course with the participation of a tutor

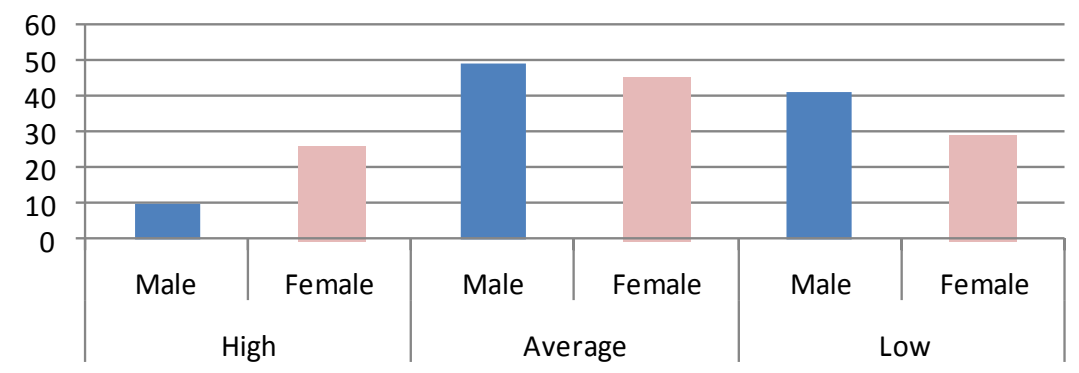

Source: Authors

In this case, the respondents could select one from three responses; hence the evaluations (low, average, high). According to the results obtained, students prefer the presence of a tutor on their courses. Gender contingency dependence is very strong $(0,901)$, but $\mathrm{X}$-square of the evaluation of responses indicates the statistical significance (0.003), which is certainly due to the different approaches and relationships to types of communication in both genders (female students probably prefer a personal form of communication). This finding supports the active management of the educational process even with the active use of ICT. Other questions in the survey were related to opinions on management simulations. They were mainly about their views on the interest, its ability to support creativity, and about the strengthening of the characteristics of the team and the opportunity to learn new features of their gaming partners - team members. 


\section{Perception of managerial simulations as interesting (Fig. 6)}

Only $6 \%$ of respondents at the Faculty of Management PU considered managerial simulations unattractive. The most frequent answer was "high" and hence for most students the managerial simulations were very interesting. There is no difference between the opinions (answers) of men and women (the dependence of opinion from both classification criteria is again strong; Chisquare refers to a statistically insignificant difference). Significantly the preference for using simulations as a tool for the development of managerial competencies for future work of students indicates the popularity of simulation programmes in today's world of ICT. It indicates the great popularity of managerial games for university students, for whom there is no problem in the availability of ICT and access to different game simulations in leisure time. It is therefore a confirmation of the suitability of the "learning through play" approach and preferences and creative approaches regardless the age of the participants.

Figure 6 Attractiveness of managerial simulations

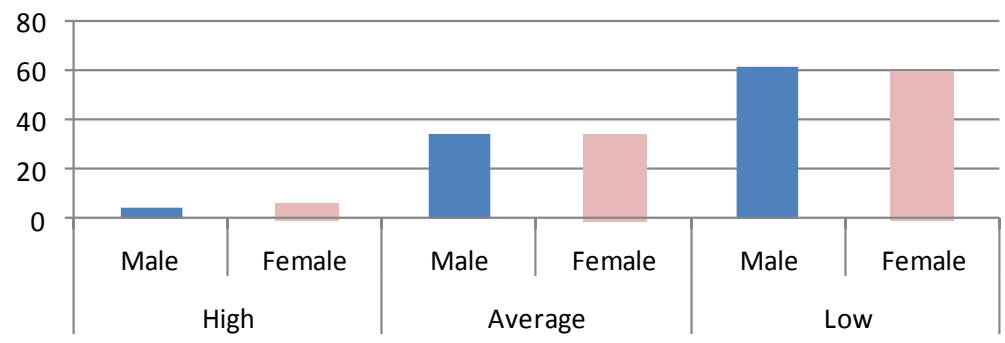

Source: Authors

\section{Managerial simulation in terms of encouraging creativity (Fig. 7)}

The results of the survey correspond to the proclaimed support for creativity in the educational system in the EU in that the respondents - university students positively evaluated managerial simulations in terms of encouraging creativity. The result was the same as in the previous question relating to interest. The participating students realized that management simulation supports their creativity, women (naturally) more than men. This positive perception of the creativity support provided by managerial simulations is supportive for teachers who are in the business of educating future managers. Dependence of opinions by gender is strong (0.943) again and chi-square points to statistically significant differences between male and female students again. 
Figure 7 Perceptions of creativity support in managerial simulation

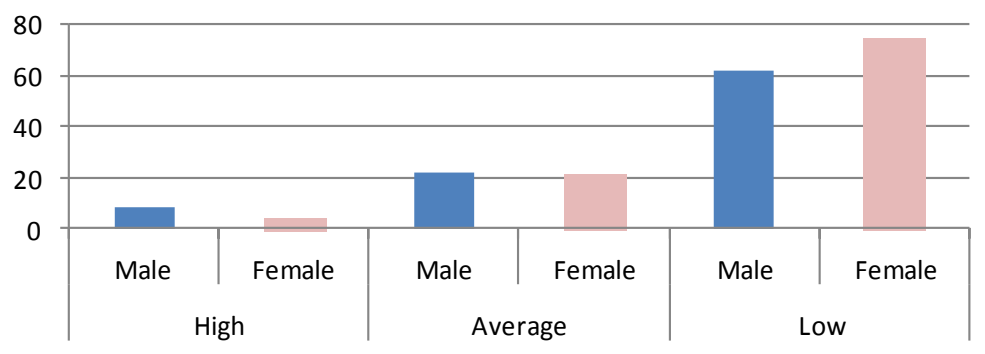

Source: Authors

\section{Managerial simulations support team approach (Fig. 8)}

Students work in teams during managerial simulations. This teaches them cooperation and brings their action closer to the real environment. There is a strengthening process of teambuilding; students learn to work together, to communicate with each other within the team; but discover also the problems of team working. Even when answering this question, there was no change of statistical indicators; dependence of opinions on gender was strong, the differences were not statistically significant, although at first glance it is to be seen that the feminine part of the population is more inclined to a team approach in problem solving than male students. We can say that students, prospective managers who have been through simulations supported by means of ICT, rate them as very suitable for strengthening relationships in the team and for teambuilding. Since today's modern trends in work currently require a team approach, the inclusion of practice-based simulation games are a convenient method of preparing for future employment.

Figure 8 Managerial simulations support team approach

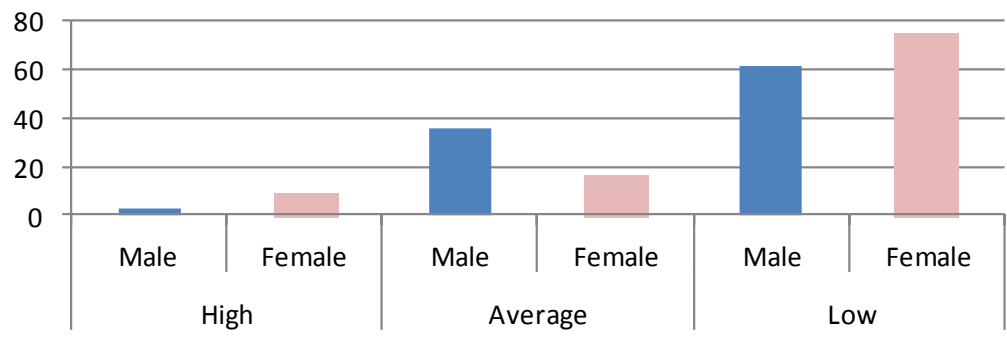

Source: Authors 


\section{Managerial simulations allow learning new features of the game-mates}

In this question, there was almost no change in the answers of respondents compared to the previous issue (that's why it won't be shown graphically). Statistical evaluation confirmed once again a strong relationship between classification features and opinions $(0,972)$; the major differences were in the result of the Chi-square test, but they were also statistically insignificant differences (0.279). The diversity of opinions is statistically not confirmed. As in previous issues, there is a significantly positive opinion about the opportunity to learn new features. This result shows that suitably selected managerial simulations can also be used as a means of getting to know others (teammates) and can also lead to teambuilding.

\section{Discussion}

After evaluation of the responses to the questionnaire items selected for survey, we can conclude that creative approaches to teaching future managers through ICT methods (in the form of online course management and simulation exercises) is, in the minds of respondents, perceived positively. Similarly positive are their opinions on the attractiveness, creativity, the importance of creating the team and getting to know new characteristics of team players. This result also corresponds with the opinions presented by authors from other literary sources. There haven't demonstrated differences in opinion by gender; contingency dependency has been strong in all cases surveyed.

The correctness of the creative approaches trend in the educational process was confirmed; at universities it is naturally a process supported by means of ICT.

\section{Conclusions}

Successful electronic courses and managerial simulations create in the educational process a unique atmosphere that positively affects people's behaviour in both the short and longer terms. One cannot expect that the informality of contacts arising from managerial simulations (which naturally "begin to surface" from the character of collaborative tasks and from open and creative atmosphere) will fully survive a return to a classical environment. In different game situations some hidden personality features of each participant stand out.

Non-traditional forms of education undoubtedly lead to a deeper selfunderstanding and mutual awareness between actors. Based on our experience, we do not recommend an over-reliance on these new findings, especially not using them mechanically to compare the behaviour of different people. Simulations and courses do not represent the same burden for all participants. For one they are easy to handle, for another they can be stressful. It is necessary to consider knowledge from such activities as one source of information that 
should always be considered in the context of previously known facts. The participants' expressions are mainly situational and therefore it is not possible to generalize about them.

It is necessary to realize that both the development and implementation of online courses, as well as practical work in the form of computerized managerial simulations that lead to learning and personal development, are very demanding, which requires facilitators (trainers, teachers) to possess professional knowledge and skills in the fields of management, social psychology, pedagogy and various other fields, and requires a certain degree of creativity, but especially, a significant degree of human maturity.

Educational institutions in Slovakia face the challenge of constantly updating their training programs in terms of content, but also the form of education. The changing society, changing educational requirements, the need for adult education in the form of retraining courses, skills training as well as the undertaking a course at a time that is most suitable for participants - these phenomena create the need for electronic courses and their wares. The possibilities of using online courses and support of the educational process can be different. It may be:

- consultancy support implemented through regular meetings (individual or within a particular group),

- e-mail communication between the tutor (lecturer) on one side and the students or whole group on the other side, in which they can advise each other or point out some problems and possible solutions.

Due the popularity of internet and e-learning courses, it can be stated that their use is currently behind their expected uptake. According to other authors (Hanuš, 2002; Másilka, 2003; Hanuš and Chytilová, 2009), we outline some of the causes and reasons for this situation:

- ICT implementation is dependent on the specific amount of funds of individual users - that's why the internet access (ensuring adequate provision of sufficient software for comfortable simulations) is from financial perspective often complicated;

- school managements, due to limited financial resources, cannot provide sufficient increased funds in real time for the material and technical support for education;

- the lack of motivation on any innovative efforts of many teachers, university lecturers not excluding;

- prevailing lack of institutional support, e.g. formation of professional teams of teachers and technicians;

- geographical distance between the student or course participant and the educational institutions.

Based on the authors' personal experiences, we can note that from the teacher's side the important factors in the educational process supported by means of ICT are: 
- exploitation of creativity through the creation of a positive climate in the classroom;

- support of emotional expression;

- support of verbal communication ("live" lessons in a virtual classroom).

Despite the great declaration of the need for education via ICT support, the supply of online courses for schools and universities in Slovakia is still lagging. The perspectives on the implementation of online courses have their theoretical and practical upshot. Theoretically, under the action of the running flow the comfort zone is constantly growing. The practical results of an online course for students points to the disadvantages and reasons that cause some degree of insufficiency. Nevertheless, it can be stated that the popularity of such courses and the use of managerial simulations is for students - future managers desirable and highly effective. That's why the creative methods will have an irreplaceable place in managing education in the future. They are one of the teaching methods, which represent "learning through play" with a focus on the experiential form of teaching. In a nonviolent, effective (sometimes spectacular) way, the students develop the knowledge, skills and competencies that are needed in the current turbulent workplace.

\section{References}

ADAIR, J. Jak efektívně vést druhé. Praha: Management Press, 1993.

ALI TAHA, V. and TEJ, J. Tvorivé metódy v manažmente. Prešov: Bookman, 2012.

ATKINSON, R. and FLINT, J. Accessing Hidden and Hard-to-Reach Populations: Snowball Research Strategies Social Research Update [online]. 2001 [viewed 24 April 2013]. Available from:

http://sru.soc.surrey.ac.uk/SRU33.html

BALOGOVÁ, B. Interkulturálne tréningy navodzujú atmosféru dôvery [online]. 2009 [viewed 1 March 2011]. Available from:

http://podnikanie.etrend.sk/podnikanieriadenie/interkulturalne-treningynavodzuju-atmosferu-dovery.html .

BEERMANN, S. and SCHUBACH, M. Hry na semináre a workshopy. Praha: Grada Publishing, 2009.

BIRKNEROVÁ, Z. The Use of Simulation Business Games in University Education. Bulgarian Journal Science \& Education Policy, 4(2), 202-215.

BURGEROVÁ, J. Internet vo výučbe a štýly učenia. Prešov: PU v Prešove, 2001.

BRUNDAGE, D., KEANE, R. and MACKNESON, R. Application of learning theory to the instruction of adults. In: Distance Education at a Glance. Guide 8: Strategies for Learning at a Distance [online]. 1993 [viewed 5 December 2011]. Available from: http://www.uiweb.uidaho.edu/eo/dist8.html

FRANC, D. et al. Učení zážitkem a hrou. Brno: Computer Press, 2007. 
GOREJ, L. Škola - dielňa tvorivosti [online]. Bratislava: MPC v Bratislave, 2010 [viewed 20 April 2012]. Available from:

http://www.mpc-edu.sk/library/files/gorej_skola_dielna_tvorivosti.pdf

HANUŠ, R. Zážitková pedagogika. HNUTÍ GO!, vzdelávací semináŕ, 2002.

HANUŠ, R. and CHYTILOVÁ, L. Zážitkově pedagogické učení. Praha: Grada Publishing, 2009.

JURKOVÁ, J. and FERENCOVÁ, M. Využívanie interaktívnych metód výučby - súčast' prípravy pre prax. Didaktika, 2011, 2(1), 26 - 29.

KROUWEL, B. and GOODWILL, S. Management Development Outdoor. London: Kogan Page, 1994.

KRŠÁKOVÁ, Z. Manažérske hry. Bratislava: Ekonóm, 2005.

LUTICOVÁ, G., SKLADANOVÁ, D. and TEJ, J. e-Ekonómia - virtuálne kurzy ekonómie pre stredoškolákov [online]. 2001 [viewed 23 April 2013]. Available from: http://e-ekonomia.infovek.sk/vstup.php

MÁSILKA, D. Vliv vědeckého paradigmatu vnímání světa na výchovněvzdělávací př́stupy: holismus a zážitková pedagogika. In: Co je zážitková pedagogika [online]. 2003 [viewed 23 April 2012]. Available from:

http://www.os-atmosfera.net/?id=zazitkova_pedagogika

STRAKOVÁ, Z., PRČÍKOVÁ, M. and CIMERMANOVÁ, I. Vybrané aspekty pripravy kurzov dištančného vzdelávania. Prešov: FHPV PU v Prešove, 2004.

SVATOŠ, V. and LEBEDA, P. Outdoor trénink pro manažery a firemní týmy. Praha: Grada Publishing, 2005.

TEJ, J. and ALI TAHA, V. Analytical insight into problems of vocational education in the Slovak republic. Problems of education in the 21st century, 2011, 34(1).

TEJ, J. and KRASNODĘBSKI, A. Skúsenosti s vyučovaním manažérskych predmetov na zahraničnej vysokej škole. In: Multikulturalita a komunikatívne kompetencie. Prešov: FHPV PU v Prešove, 2009.

Závery Rady a zástupcov vlád členských štátov, ktorí sa zišli na zasadnutí Rady z 21. novembra 2008, o príprave mladých l'udí na 21. storočie: agenda pre európsku spoluprácu v školstve. Brusel. 2008.

http://eur-

lex.europa.eu/LexUriServ/LexUriServ.do?uri=OJ:C:2008:319:0020:0022:SK:P

DF [viewed 23 April 2013].

http://www.jasr.sk/showdoc.do?docid=1981 [viewed 30 April 2013].

Acknowledgements

The article is part of the solution of the research grant project KEGA 017PU$4 / 2013$ „Networking of selected elements of faculty structure“. 